\title{
CLINICAL AND IMMUNOLOGICAL PRESENTATION OF ATAXIA-TELANGIECTASIA
}

\section{Oksana BOYARCHUK ${ }^{1}$, Larysa KOSTYUCHENKO르, Alla VOLOKHA ${ }^{3}$, Anastasiia BONDARENKO ${ }^{3}$, Anna HILFANOVA ${ }^{3}$, Yaryna BOYKO ${ }^{2}$, Mariya KINASH ${ }^{1}$, Tetyana HARIYAN ${ }^{1}$, Yuriy STEPANOVSKYY ${ }^{3}$, Liubov VOLIANSKA ${ }^{1}$, Liudmyla CHERNYSHOVA ${ }^{3}$}

${ }^{1}$ Department of Children's Diseases and Pediatric Surgery, I. Horbachevsky Ternopil National Medical University, Ternopil, Ukraine

${ }^{2}$ Pediatric Immunology and Rheumatology Clinic, Western-Ukrainian Specialized Children's Medical Centre, Lviv, Ukraine

${ }^{3}$ Department of Pediatric Infectious Diseases and Pediatric Immunology, Shupyk National Medical Academy of Postgraduate Education, Kyiv, Ukraine

Received 07 Sept 2020, Accepted 29 Oct 2020

hitps://doi.org/10.31688/ABMU.2020.55.4.03

\section{Abstract}

Introduction. Ataxia-telangiectasia (A-T) is a neurodegenerative disorder characterised by progressive ataxia, telangiectasia, immunodeficiency, increased susceptibility to malignancies and radiation sensitivity.

The objective of the study was to determine the clinical and immunological features, as well as the consequences of A-T in the Ukrainian population.

Material and methods. Sixty-four patients with A-T, registered at the Ukrainian National Registry of primary immunodeficiencies, were first included in the study. The evaluation of clinical signs and investigations were possible in 53/64 patients with A-T.

Results. Neurological signs and telangiectasies were evidenced in all patients, and were followed by recurrent infections (81.1\%), lymphoid hypoplasia (66.0\%), and malignancies (15.1\%). Poor weight gain was observed in $73.6 \%$ of patients, orthopaedic disorders in $52.8 \%$, and bronchiectasis in $30.8 \%$. High alpha-fetoprotein levels were seen in $93.5 \%$ of patients, mean level-150.3 IU/mL. Among immunoglobulin changes,

\section{Résumé}

Présentation clinique et immunologique de l'ataxie-télangiectasie

Introduction. Lataxie-télangiectasie (A-T) est une maladie neurodégénérative caractérisée par une ataxie progressive, une télangiectasie, une immunodéficience, une susceptibilité accrue aux tumeurs malignes et une sensibilité aux radiations.

Le but de l'étude était de déterminer les caractéristiques cliniques et immunologiques, ainsi que les conséquences de l'ataxie-télangiectasie (A-T) dans la population ukrainienne.

Matériel et méthodes. Soixante-quatre patients atteints d'A-T, enregistrés au Registre national ukrainien des déficits immunitaires primaires, ont été analysés. L'évaluation des signes cliniques et des investigations ont été possibles chez 53/64 patients atteints d'A-T.

Résultats. Des signes neurologiques et des télangiectasies ont été mis en évidence chez tous les patients et ont été suivis d'infections récurrentes $(81,1 \%)$, 
the most significant was a decreased IgA level (83.0\%), followed by a high IgM level (50.9\%), low IgG (18.9\%) and $\mathrm{IgE}$ levels (49.1\%). Reduced CD3, CD4 and CD8 T-lymphocytes were observed in $85.7 \%$ of patients. Infections and cancer were the most often causes of mortality. The mean age at death was 14.1 years, ranging from 6 to 21 years.

Conclusions. Ataxia in combination with recurrent infections is the key to A-T diagnosis. In addition to syno-pulmonary infections, pyoderma and stomatitis are also frequent presentations. Children with ataxia should be referred to an immunologist, as well as genetic testing should be recommended for all patients with ataxia for timely diagnosis.

Keywords: ataxia-telangiectasia, clinical presentation, immunological features.

\section{List of abbreviations:}

AFP - alpha-fetoprotein

ATM - ataxia-telangiectasia mutated

A-T - ataxia-telangiectasia

CBC - complete blood count

DNA - deoxyribonucleic acid

ESID - European Society for Immunodeficiencies

Ig - immunoglobulin

IVIG - intravenous immunoglobulin

JIA - juvenile idiopathic arthritis

MRI - magnetic resonance imaging

PID - primary immunodeficiency

\section{INTRODUCTION}

Ataxia-telangiectasia (A-T), also known as LouisBar's syndrome, is an autosomal recessive neurodegenerative disorder characterized by progressive ataxia, telangiectasia, immunodeficiency, increased susceptibility to malignancies and radiation sensitivity $^{1-2}$. The disease is caused by a mutation of the Ataxia Telangiectasia Mutated (ATM) gene, encoding for the ATM protein ${ }^{2 \cdot 3}$. A-T also refers to DNA damage response syndromes ${ }^{1-2}$.

Ataxia is the main neurological manifestation of the disease, that is recognized when the baby starts walking or sitting ${ }^{1-2}$. Progressive ataxia leads to disability and seriously reduces the quality of life in patients with $A-T^{1-2}$. The patients with ataxia are often monitored by neurologists due to different neurological diagnosis before other characteristic signs or manifestations of immunodeficiency occur ${ }^{1,4}$.

A-T refers to a group of combined immunodeficiencies with associated or syndromic features ${ }^{5}$. Immunodeficiency in patients with A-T is mostly manifested by sino-pulmonary infections and in more d'hypoplasie lymphoïde $(66,0 \%)$ et de tumeurs malignes $(15,1 \%)$. Une faible prise de poids a été observée chez $73,6 \%$ des patients, des troubles orthopédiques chez $52,8 \%$ et une bronchectasie chez $30,8 \%$. Des taux élevés d'alphaphœtoprotéine ont été observés chez $93,5 \%$ des patients, taux moyen de 150,3 UI / ml. Parmi les changements d'immunoglobuline, le fait le plus significatif était une diminution du taux d'IgA (83,0\%), suivie d'un taux élevé d'IgM (50,9\%), de faibles taux d'IgG (18,9\%) et d'IgE (49,1\%). Des lymphocytes T CD3, CD4 et CD8 réduits ont été observés chez $85,7 \%$ des patients. Les infections et le cancer étaient les causes les plus fréquentes de mortalité. L'âge moyen de décès était de 14,1 ans, allant de 6 à 21 ans.

Conclusions. L'ataxie associée à des infections récurrentes est la clé du diagnostic de l'A-T. En plus des infections synoviales pulmonaires, la pyodermie et la stomatite sont également des manifestations fréquentes. Les enfants atteints d'ataxie doivent être référés à un immunologiste, et des tests génétiques doivent être recommandés à tous les patients atteints d'ataxie pour un diagnostic rapide.

Mots-clés: ataxie-télangiectasie, présentation clinique, caractéristiques immunologiques.

than $25 \%$ of A-T cases chronic lung disease develops $^{1,6,7}$.

One of the most serious manifestations of A-T is malignancy ${ }^{1,3}$. About $25 \%$ of the A-T patients suffer from cancers ${ }^{1,8-9}$. A-T heterozygotes have also an increased risk of cancer, especially breast cancer $(15 \%)^{1}$. Other manifestations of A-T include increased sensitivity to radiation, growth retardation, autoimmune disorders, endocrine disorders, early skin aging, cognitive impairments, and orthopaedic problems ${ }^{1,3,10}$. Knowledge about clinical and immunological features of A-T may help physicians with timely diagnosis and management of the disease.

The objective of THE Study was to determine the clinical and immunological presentation, and consequences of A-T in the Ukrainian population.

\section{Materials AND MEthods}

64 patients (53 families) with A-T, registered in the Ukrainian National Registry of primary immunodeficiencies, were involved in this study. A-T cases 
have been diagnosed and registered in Ukraine since 1996. There were 5 families with two children and 3 families with three children with A-T. Six living patients have reached 18 years of age.

The diagnosis of A-T was based on clinical symptoms, genetic and biochemical tests according to the European Society for Immunodeficiencies (ESID) criteria for clinical diagnosis of A-T ${ }^{11}$. The registry data included the date and place of patient's birth, age at the disease manifestation onset, age at diagnosis, patient's status (alive or dead), cause of death, genetic diagnosis.

In addition, a questionnaire with detailed information about clinical signs (neurological findings, telangiectasia, infections, bronchiectasis, malignancies, allergies, and autoimmune disorders), complete blood count (CBC), alpha-fetoprotein (AFP) level, immunological examinations, neuroimaging, genetic diagnosis, treatment options of the patients with A-T was developed. Immunologists following-up the children with A-T were invited to fill in the questionnaires. The information about clinical signs and examinations results were provided for 53 patients affected by A-T.

Informed consent was obtained from all living adult participants in the study or from the parents of patients $<18$ years old. The experiment records were conducted following the guidelines of the Helsinki Declaration of 1975, as revised in 2000.

The statistical analysis was carried out using the statistical package STATISTICA 10.0 and table editor Microsoft Excel 2003. Continuous variables were expressed as means and SDs. The comparison of frequency parameters was performed using the $\chi^{2}$ test. To determine the rank measure of association the Spearman's correlation coefficient was calculated. Kaplan Meier survival analysis was used to determine the survival probability of patients. The differences between the parameters were statistically significant at $p<0.05$.

\section{Results}

\section{Demographic and clinical features}

According to the registry, from 64 patients with A-T, 33 are currently alive, 27 have died and 4 were lost to follow-up. The demographic features of the patients are presented in Table 1. There were two families where 2 children died and two families in which three children died because of A-T. There were no twins among the A-T patients; the parents did not report about any parental consanguinity, as well.

The mean onset age of the first A-T signs was 14.9 months, ranging from 3 months to 3 years. Commonly, A-T manifested with ataxia (56/87.5\%). However, in some cases the first clinical manifestation was telangiectasia, which occurred in one patient at 3 months of age, or respiratory infections, pyelonephritis. The clinical manifestations of A-T patients are presented in Table 2. Ataxia occurred in all patients. The mean age of ataxia onset was 16.4, ranging from 6 months to 3 years. In $82.8 \%$ of patients, ataxia manifested before the age of 2 years. Commonly, the initial diagnosis in patients with A-T was cerebral palsy or ataxic syndrome. Less often myotonic syndrome, neurodegeneration with ataxia, or motor delay were registered. One child was misdiagnosed with Silver-Russell syndrome.

Dysarthria and oculomotor apraxia were less frequent, followed by loss of ability to walk and nystagmus. Most of the observed children (64.2\%) required a wheelchair by the average age 7.9 years, range $6-12$ years. Swallowing difficulties occurred in $13.2 \%$, and intention tremor and myoclonic jerks in some cases.

Telangiectasies first appeared from 3 months to 12 years, the average age was 4.1 years. Ocular and skin telangiectasia occurred most often. Sometimes, ocular telangiectasia was misdiagnosed as allergic conjunctivitis. Almost a third of A-T patients presented with "café au lait" spots, vitiligo and follicular keratosis. Nevi, skin atrophy rarely occurred and seborrheic dermatitis was observed in one patient.

Lymphoid hypoplasia was observed as lymph nodes and tonsillar hypoplasia $(66.0 \%$ and $64.2 \%$, respectively). Evidence of thymic hypoplasia was present only in four patients; in other cases, these data were unclear.

Recurrent infections occurred in $81.1 \%$ of patients. Commonly bronchitis, pneumonia, pharyngitis/tonsillitis and sinusitis occurred (Table 2). Otitis, stomatitis, pyoderma and enterocolitis were observed less frequently. Warts, pyelonephritis, mycoses,

Table 1. Demographic features of the A-T patients.

\begin{tabular}{lc}
\hline Characteristic features & Total $(n=64)$ \\
\hline $\begin{array}{l}\text { Age, mean } \pm \text { SD, years; } \\
\text { (range) }\end{array}$ & $14.8 \pm 7.1 ;(6-27)$ \\
\hline $\begin{array}{l}\text { Gender, male, n (\%) } \\
\text { female, n (\%); sex ratio }\end{array}$ & $34(53.1 \%) / 30(46.9 \%) ; 1.13$ \\
\hline $\begin{array}{l}\text { Mean age at diagnosis, } \\
\text { years; (range) }\end{array}$ & $6.2(1-16)$ \\
\hline $\begin{array}{l}\text { Mean delay in diagnosis, } \\
\text { years; (range) }\end{array}$ & $5.0(0-13)$ \\
\hline $\begin{array}{l}\text { Living conditions, urban/ } \\
\text { rural }\end{array}$ & $22 / 42$ \\
\hline $\begin{array}{l}\text { Alive, n (\%); mean age, } \\
\text { (range) }\end{array}$ & $33(51.6 \%) ; 14.1 \pm 5.8,(6-27)$ \\
\hline $\begin{array}{l}\text { Death, n (\%); mean age, } \\
\text { (range) }\end{array}$ & $27(42.2 \%) ; 14.1 \pm 5.7,(6-21)$ \\
\hline $\begin{array}{l}\text { Lost to follow-up, n (\%); } \\
\text { mean age, (range) }\end{array}$ & $4(6.2 \%) ; 22.5 \pm 12.2,(6-35)$ \\
\hline
\end{tabular}


Table 2. Clinical signs in patients with A-T.

\begin{tabular}{|c|c|c|}
\hline Sign & $n$ & $\%$ \\
\hline Neurological signs: & $64 / 64$ & 100 \\
\hline ataxia & $64 / 64$ & 100 \\
\hline dysarthria & $45 / 53$ & 84.9 \\
\hline loss of ability to walk & $34 / 53$ & 64.2 \\
\hline oculomotor apraxia & $39 / 53$ & 73.5 \\
\hline nystagmus & $22 / 53$ & 41.5 \\
\hline swallowing difficulties & $7 / 53$ & 13.2 \\
\hline Telangiectasia: & $64 / 64$ & 100 \\
\hline ocular & $15 / 64$ & 23.4 \\
\hline ocular and skin & $49 / 64$ & 76.6 \\
\hline \multicolumn{3}{|l|}{ Skin manifestations: } \\
\hline café au lait spots & $18 / 53$ & 34.0 \\
\hline nevi & $4 / 53$ & 7.5 \\
\hline vitiligo & $17 / 53$ & 32.1 \\
\hline follicular keratosis & $16 / 53$ & 30.2 \\
\hline skin atrophy & $3 / 53$ & 5.7 \\
\hline \multicolumn{3}{|l|}{ Lymphoid hypoplasia: } \\
\hline lymph nodes & $35 / 53$ & 66.0 \\
\hline tonsils & $34 / 53$ & 64.2 \\
\hline Recurrent infections: & $43 / 53$ & 81.1 \\
\hline bronchitis & $35 / 53$ & 66.0 \\
\hline pneumonias & $23 / 53$ & 43.4 \\
\hline otitis & $10 / 53$ & 18.9 \\
\hline sinusitis & $15 / 53$ & 28.3 \\
\hline pharyngitis/tonsillitis & $16 / 53$ & 30.2 \\
\hline warts & $2 / 53$ & 3.8 \\
\hline Molluscum contagiosum infection & $1 / 53$ & 1.9 \\
\hline enterocolitis & $6 / 53$ & 11.3 \\
\hline stomatitis & $11 / 53$ & 20.8 \\
\hline pyoderma & $13 / 53$ & 24.5 \\
\hline mycoses & $4 / 53$ & 7.5 \\
\hline pyelonephritis & $4 / 53$ & 7.5 \\
\hline Herpes simplex infection & $4 / 53$ & 7.5 \\
\hline Bronchiectasis & $12 / 39$ & 30.8 \\
\hline Autoimmune diseases: & $4 / 53$ & 7.5 \\
\hline thrombocytopenia & $2 / 53$ & 3.8 \\
\hline arthritis & $2 / 53$ & 3.8 \\
\hline Malignancies: & $8 / 53$ & 15.1 \\
\hline leukaemia & $1 / 53$ & 1.9 \\
\hline lymphoma & $6 / 53$ & 11.3 \\
\hline carcinoma & $1 / 53$ & 1.9 \\
\hline Allergies: & $9 / 53$ & 17.0 \\
\hline eczema & $9 / 53$ & 17.0 \\
\hline asthma & $2 / 53$ & 3.8 \\
\hline allergic rhinitis & $4 / 53$ & 7.5 \\
\hline Orthopaedic manifestations: & $28 / 53$ & 52.8 \\
\hline acquired foot deformity & $23 / 53$ & 43.4 \\
\hline scoliosis & $21 / 53$ & 39.6 \\
\hline
\end{tabular}

Herpes simplex infection and Molluscum contagiosum infection occurred in some cases.

Bronchiectasis was confirmed by computed tomography of the chest in $30.8 \%(12 / 39)$ of the examined patients with history of recurrent pulmonary infections. Interstitial lung disease was demonstrated in one patient.

Autoimmune diseases occurred rarely (7.5\%), with thrombocytopenia in two cases and arthritis also in two cases. Allergies were observed in $17.0 \%$ of the patients and commonly manifested as eczema.

Malignancies occurred in $15.1 \%$, most commonly lymphomas (6 cases): 5 non-Hodgkin's and one Hodgkin's lymphoma. Leukaemia occurred in one patient, and a single thyroid gland carcinoma. Leukaemia and lymphoma developed in all patients before 10 years of age.

A family history of cancer occurred in 9/53 (17.0\%) patients with A-T, most commonly colon cancer (3 cases), lung cancer ( 3 cases), and leukaemia (2 cases). Other malignancies in close relatives included breast, prostate, bladder, throat, brain, skin cancers, and hepatocarcinoma.

Orthopaedic manifestations were present in $52.8 \%$ of the patients. Acquired foot deformity occurred most often, followed by scoliosis. Contractures, kyphosis, flat feet occurred in rare cases.

Poor weight gain was evident in 39/53 (73.6\%) patients and growth delay in 20/53 (37.7\%) patients. The mean weight for age $z$-score was $-2.9 \pm 2.1$, with the lowest value -6.3 , and the mean height for age $z$-score was $-1.9 \pm 1.4$, with the lowest value -4.7 .

Among other manifestations, gastric ulcer, liver angiomatosis, epileptic syndrome, congenital heart disease and coloboma were observed in rare cases.

\section{Laboratory findings}

Laboratory testing demonstrated anaemia in $10 / 53(18.9 \%)$ patients, leukopenia in $11 / 53$ (20.8\%) patients, with the lowest value $2.7 \times 10^{9} / \mathrm{L}$. Lymphopenia was observed in 37/53 (69.8\%) patients, with a mean value of $(1.78 \pm 0.91) \times 10^{9} / \mathrm{L}$. The erythrocyte sedimentation rate (ESR) was increased in 23/53 (43.4\%) patients, although the platelet count was consistently normal.

Alpha-fetoprotein (AFP) levels were raised in $93.5 \%(43 / 46)$ patients, with a mean value of 150.3 $\mathrm{IU} / \mathrm{mL}$, range $1.7-402.7 \mathrm{IU} / \mathrm{mL}$. AFP levels were in the normal range in only 3 cases: at ages 2.5, 9 and 14 years, all currently alive, with only mild neurological and immunological changes. There was a significant positive correlation between the patient's age and AFP level $(r=0.5654, p<0.05)$. There was no relation between AFP level and malignancy in patients with A-T. 
Table 3. Immunoglobulin levels in patients with A-T $(n=53)$.

\begin{tabular}{cccc}
\hline Immunoglobulin $(\mathrm{Ig})$ & Deviation & $n(\%)$ & $\mathrm{M} \pm$ SD, range \\
\hline $\operatorname{Ig~G}, \mathrm{g} / 1$ & decreased & $10(18.9)$ & $8.51 \pm 4.16(0.18-19.52)$ \\
\hline $\operatorname{Ig~A}, \mathrm{g} / \mathrm{l}$ & decreased & $44(83.0)$ & $0.30 \pm 0.35(0-1.43)$ \\
\hline $\operatorname{Ig~M}, \mathrm{g} / \mathrm{l}$ & increased & $27(50.9)$ & $1.86 \pm 1.65(0.41-8.76)$ \\
\hline $\mathrm{Ig} \mathrm{E}, \mathrm{IU} / \mathrm{ml}$ & decreased & $26(49.1)$ & $60.59 \pm 162.05(0.1-700)$ \\
\hline
\end{tabular}

A

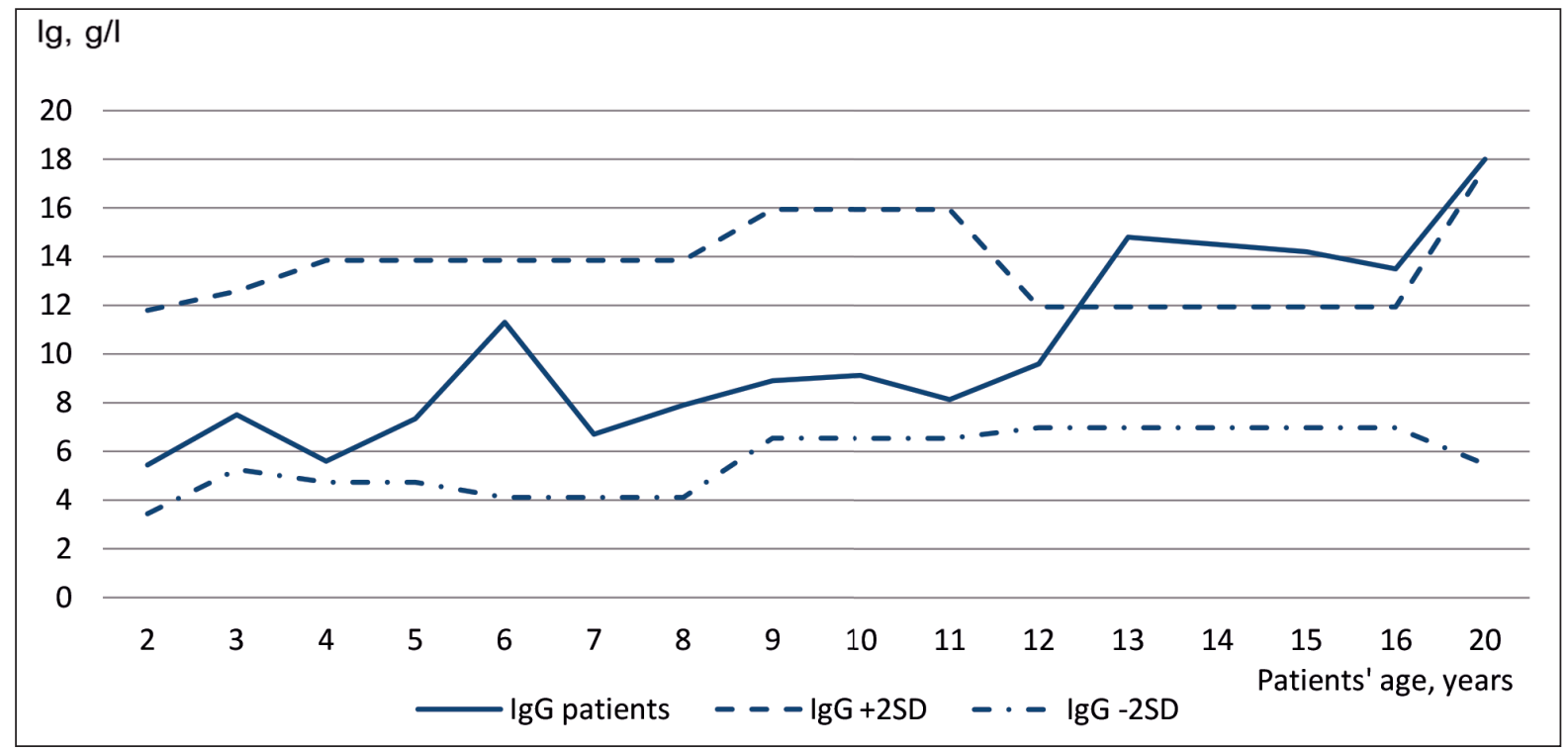

B

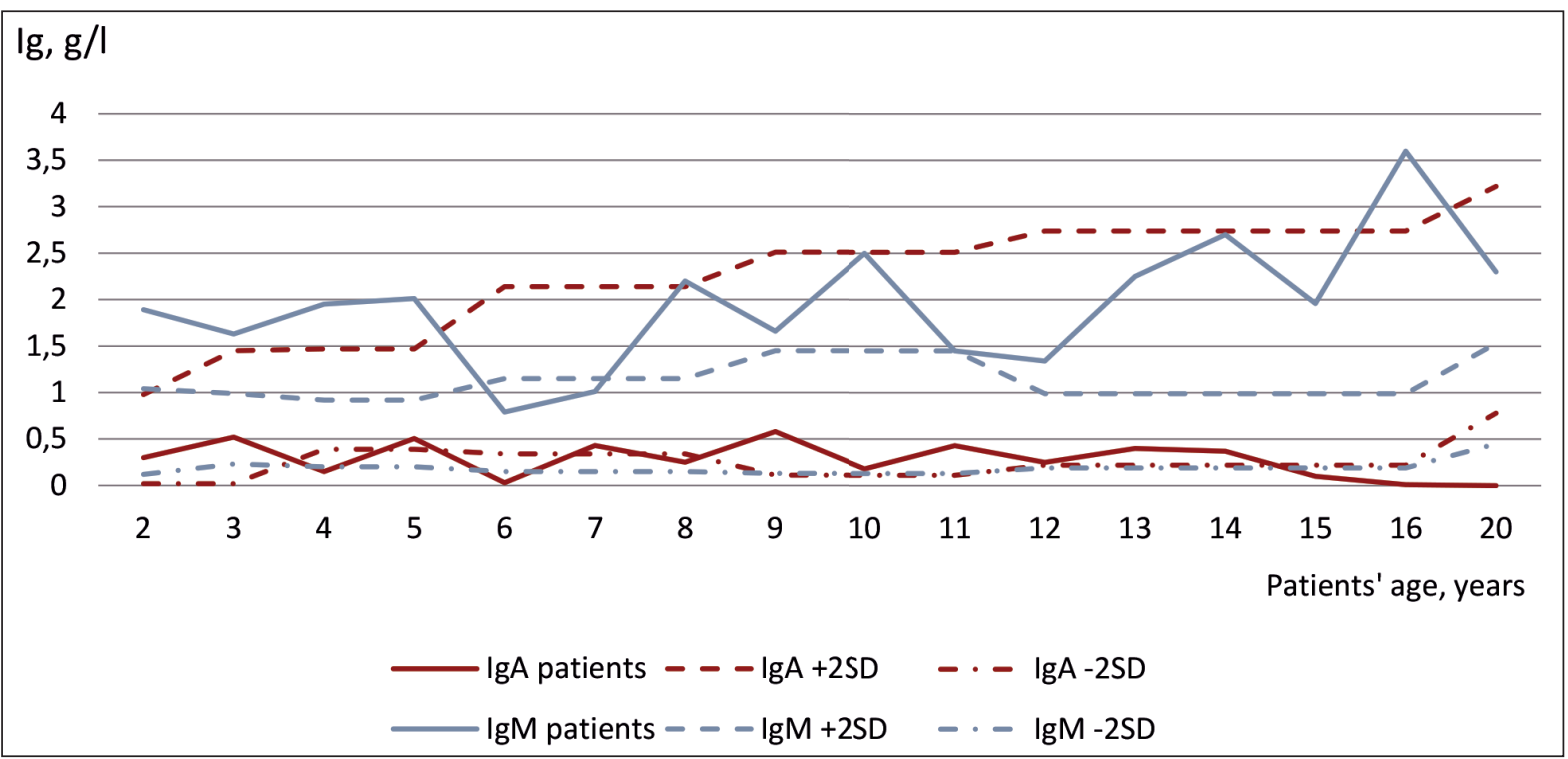

Figure 1. The relationship of the mean levels of $\operatorname{IgG}(\mathrm{a}), \operatorname{IgA}$ and $\operatorname{IgM}(\mathrm{b})$ with age.

Immunoglobulin changes occurred in 47 (88.7\%) patients. Immunoglobulin levels in the cohort of patients affected by A-T are presented in Table 3 .

The decreased IgG level was observed in $18.9 \%$ of patients; however, only in two patients its value was $<1.0 \mathrm{~g} / \mathrm{L}$ and $9 / 53(17.0 \%)$ patients had raised levels of IgG. A low IgA was commoner than a low $\mathrm{IgG}$ level (in 83.0\%, p=0.0054), with only one case with a raised level. Contrarily, IgM level was increased in $50.9 \%$ of patients. Immunoglobulin E level in $49.1 \%$ of patients was decreased and a high IgE appeared in only one patient. 
Table 4. Abnormalities of lymphocyte subpopulation levels in patients with A-T $(n=35)$.

\begin{tabular}{|c|c|c|c|c|c|c|c|}
\hline \multirow{2}{*}{ Parameter } & \multirow{2}{*}{ Abnormality } & \multicolumn{3}{|c|}{$\%$ (of lymphocytes) } & \multicolumn{3}{|c|}{ cells $/ \mathrm{mm}^{3}$} \\
\hline & & $n$ & $\%$ & $\mathrm{M} \pm \mathrm{SD}$, range & $n$ & $\%$ & $\mathrm{M} \pm \mathrm{SD}$, range \\
\hline CD3 & low level & 22 & 62.9 & $\begin{array}{c}49.43 \pm 15.43 \\
(13-80)\end{array}$ & 27 & 77.1 & $\begin{array}{c}1023.03 \pm 670.70 \\
(102-3162)\end{array}$ \\
\hline CD4 & low level & 26 & 74.3 & $\begin{array}{c}23.27 \pm 9.73 \\
(7-46)\end{array}$ & 27 & 77.1 & $\begin{array}{c}478.52 \pm 370.89 \\
(42-1900)\end{array}$ \\
\hline CD8 & low level & 23 & 65.7 & $\begin{array}{c}22.01 \pm 9.76 \\
(3-44)\end{array}$ & 25 & 71.4 & $\begin{array}{c}438.09 \pm 296.89 \\
(21-1530)\end{array}$ \\
\hline CD19 & low level & 20 & 57.1 & $\begin{array}{c}10.73 \pm 7.31 \\
(1-32)\end{array}$ & 25 & 71.4 & $\begin{array}{c}231.00 \pm 217.13 \\
(21-1071)\end{array}$ \\
\hline \multirow{2}{*}{ NK } & high level & 15 & 42.9 & \multirow{2}{*}{$\begin{array}{c}25.29 \pm 13.22 \\
(1-47)\end{array}$} & 7 & 20.0 & \multirow{2}{*}{$\begin{array}{c}507.36 \pm 469.83 \\
(36-2511)\end{array}$} \\
\hline & low level & 2 & 5.7 & & 7 & 20.0 & \\
\hline
\end{tabular}

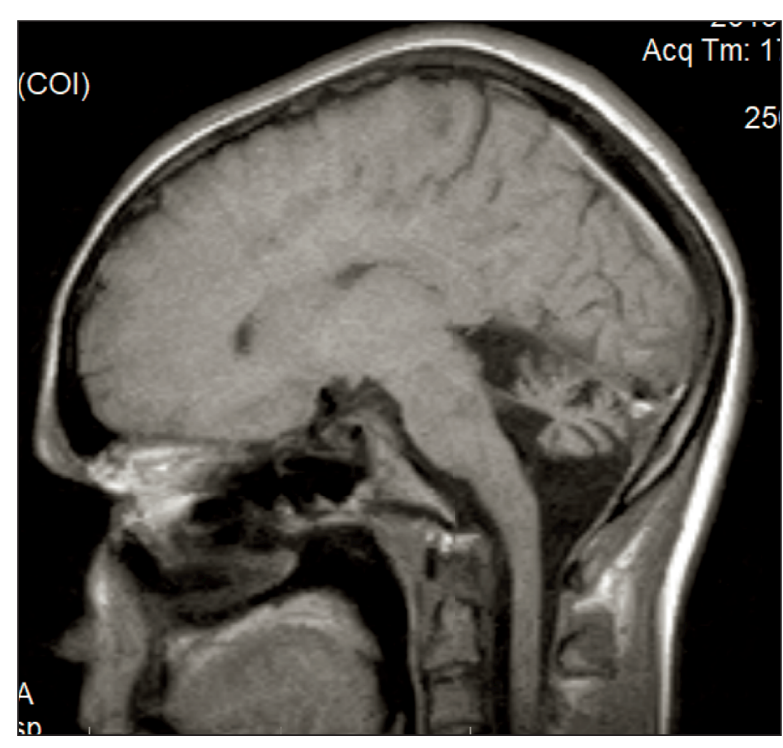

Figure 2. Cerebellar hypoplasia in a 16-year-old patient with A-T on the brain MRI.

The dependence of the mean levels of IgG, IgM, and $\operatorname{IgA}$ on age in the patients with A-T is presented in Fig. 1.

The figures show the increase of $\operatorname{IgG}$ and $\operatorname{IgM}$ levels with age; moreover, the mean levels of IgG were above the 2SD in patients over 13 years of age, whereas the mean levels of IgM were high in almost of all ages. Fluctuations in the IgA levels were insignificant, with a tendency to decrease in patients over 14 years old. There was a positive significant correlation between the IgG level and age $(\mathrm{r}=0.52 ; \mathrm{p}<0.05)$, and a negative correlation between IgG level and recurrent infections $(r=-0.35 ; p<0.05)$ in patients with A-T.

Lymphocyte subpopulation profiles were available in 35 patients with A-T. Among them, lymphocyte subpopulation abnormalities were observed in $30(85.7 \%)$ patients, although a significant decrease of CD3, CD4, CD8 and CD19 lymphocytes $(<100$ cells $/ \mathrm{mm}^{3}$ ) was revealed only in one patient, in whom lymphoma developed. The deviation of proportion and number of lymphocyte subpopulation in patients with A-T is presented in Table 4.

More than half of the examined patients with A-T presented reduced CD3, CD4 and CD8 T-lymphocytes. A decreased CD4 level was observed most often. The amount of NK lymphocytes was variable.

CT or MRI showed cerebellar atrophy or hypoplasia in 8 of 24 patients (33.3\%) (Fig. 2). The mean age of revealing neuroimaging changes was $10.0 \pm 3.3$ years old, ranging from 6 to 16 years. Vascular disorders were observed in two patients. Diffuse cerebral degenerative changes were also described in two patients.

\section{Treatment}

The main methods of treatment were immunoglobulin replacement therapy and prophylactic antibiotic therapy. Intravenous immunoglobulin replacement therapy was prescribed to 17 (32.1\%) patients, especially those with a low Ig level and/or with recurrent pulmonary infections. The mean age of starting immunoglobulin therapy was 8.3 years, ranging from 2 to 17 years. Prophylactic antibiotic therapy was administered in $16(30.2 \%)$ patients with respiratory symptoms. Amoxicillin, trimethoprim-sulfamethoxazole, and azithromycin were usually prescribed. Techniques for clearance of bronchial secretions were also used in some cases. Other treatment options included antioxidant drugs and symptomatic therapy.

\section{Outcomes}

The main causes of deaths were infections $(12 / 27,44.4 \%)$ and malignancies $(7 / 27,25.9 \%)$. In $8(29.6 \%)$ patients, the causes were unknown. Lymphoma and leukaemia led to death in 6 and one case, respectively. Among infections, pneumonia contributed to death in $9(33.3 \%)$ cases, sepsis in 2 cases, and systemic candidiasis in one case.

The Kaplan-Meier disease survival curve for patients with A-T is presented in Fig. 3. The Kaplan-Meier 


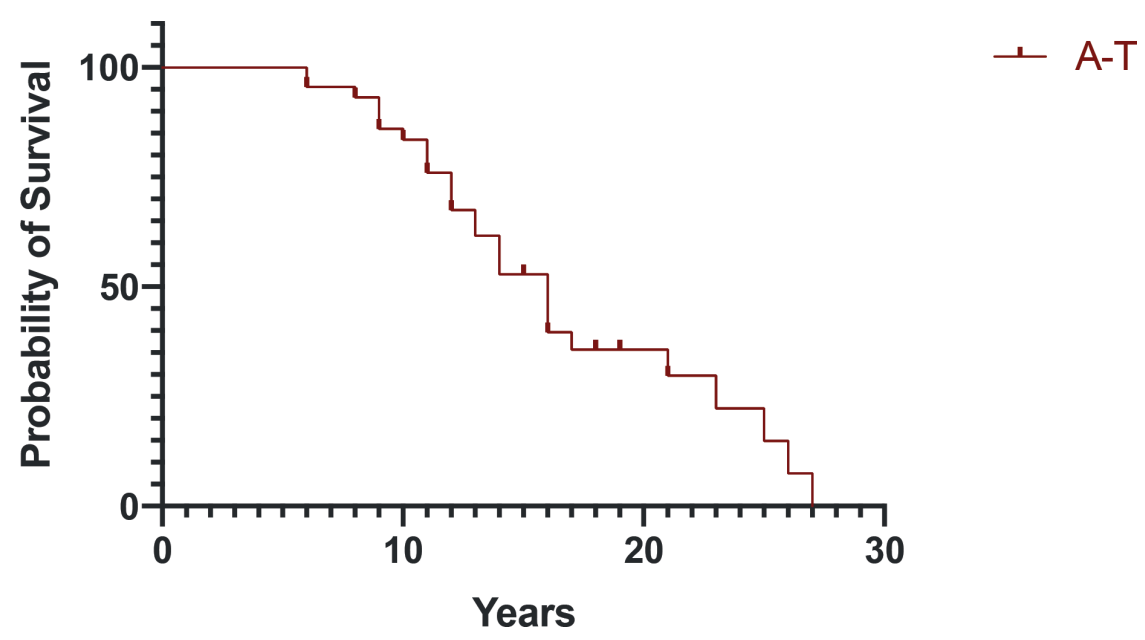

Figure 3. The Kaplan-Meier disease survival curve of the patients with A-T

median survival was 16 years. The twenty-year survival rate was estimated $35 \%$.

\section{Discussion}

The A-T cohort is one of the largest in the National registry among PIDs, therefore the evaluation of the clinical symptoms is very important for a timely diagnosis ${ }^{12-14}$. Ataxia and telangiectasia occurred in all observed patients. However, some researchers noticed that telangiectasia may be absent in some patients, even with a classic disease course ${ }^{1}$. Commonly, ataxia was the first symptom and appeared before the age of 2 years. Neuroimaging did not reveal cerebellar atrophy or hypoplasia in the first years of life, with MRI or CT changes appearing after the age 6 years. Other studies have also reported normal neuroimaging studies in the toddlers with $A-T^{1,15}$.

Recurrent infections were observed in $81.1 \%$ of the A-T patients, usually syno-pulmonary infections (bronchitis and pneumonia). Most studies also observed the predominance of syno-pulmonary infections, although some researchers indicated the prevalence of otitis $(41 \%)$ in patients with A-T, whereas bronchitis and pneumonia occurred less often (in 19\% and $15 \%$, respectively $)^{16}$. The data on other types of infections are very poor ${ }^{1,7,16}$. However, a quarter of our children with A-T suffered from pyoderma. Stomatitis, enterocolitis, pyelonephritis, mycoses, Herpes infection occurred less frequently. Warts, Molluscum contagiosum infection occurred very rarely, that is consistent with other studies ${ }^{16}$. Bronchiectasis was revealed in $30.8 \%$ of the patients with A-T. Other researchers reported similar data; chronic lung disease was diagnosed in more than $25 \%$ of the patients with A-T ${ }^{1}$.

Allergy and autoimmune diseases were rarely reported in patients with $A-T^{1,17}$. Allergies were observed in $17.0 \%$ of patients and autoimmunity in $7.5 \%$. Juvenile idiopathic arthritis (JIA) was diagnosed in a 4-year-old male patient with A-T. To the best of our knowledge, the literature has reported only two cases of JIA in patients with A-T, one of them being from our cohort ${ }^{18,19}$.

Malignancies occurred in $15.1 \%$ of the reported cohort and lymphoma was the most common. The incidence and prevalence of lymphoma are compared

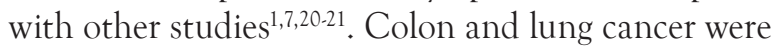
the most frequent among sibs, whereas breast, prostate and bladder cancers occurred more rarely.

Poor weight gain was more common and more significant than growth delay in the studied cohort, however, other studies reported that growth impairment was more prominent, and growth factor, hormone levels, as well as nutrition and infections contributed to this manifestation ${ }^{3,22}$

Among complete blood count testing, the most notable was lymphopenia, that occurred in $69.8 \%$ of patients with A-T, a distinguishing finding in patients with $A-T^{1,7}$, and the percentage is similar to that reported previously ${ }^{16}$.

High AFP level is one of the main laboratory features of A-T. Overall, $93.5 \%$ of patients experienced increased AFP level. The mean AFP level (150.3 IU/ $\mathrm{mL}$ ) was consistent with other researches ${ }^{23}$. Our study has proved a positive correlation between the AFP level and age, which is also reported by some researchers ${ }^{24}$.

The immunoglobulin pattern in patients with A-T showed most frequent changes of IgA, which was low in $83.0 \%$ of patients with A-T. The other significant sign was a high IgM level in $50.9 \%$ of the patients. The decrease of $\operatorname{IgG}$ and $\operatorname{IgE}$ levels occurred more rarely, in $18.9 \%$ and $49.1 \%$, respectively. Similar changes are reported in other studies ${ }^{1,6,7,25}$, however 
some researchers detected a low level of $\operatorname{IgG}, \operatorname{IgA}$ and IgE in $18 \%, 63 \%, 23 \%$, respectively, of the patients with A-T, that was slightly less than in our cohort ${ }^{16}$. We also revealed an increase of $\operatorname{IgG}$ and IgM levels with age in patients with $A-T$, whereas fluctuations in the IgA level were minor, with a tendency to decrease after 14 years. The researchers described a more severe course of the disease in cases of hyper $\operatorname{IgM}^{6,25}$.

Lymphocyte subpopulation abnormalities were evidenced in $85.7 \%$ of the patients with A-T. Most of the patients had reduced CD3, CD4 and CD8 T-lymphocytes. Most often, decreased CD4 levels were seen. There were no correlations between the numbers of T-cells and the frequency of infections. A low number of total and naive CD4 T-lymphocytes was reported in other studies ${ }^{7,25}$; other researchers outlined commonly decreased numbers of B-cells and CD4 cells ${ }^{15}$. The low numbers of naive T cells and normal terminal differentiation of antigenic stimulation of peripheral $\mathrm{T}$ cells was proved in patients with AT, therefore the patients with A-T had no clinical signs of a T-cell deficiency ${ }^{25}$. The number of NK lymphocytes in our cohort was variable; however, another study demonstrated normal levels of NK cells in patients with A-T ${ }^{25}$. Probably, the high levels of NK cells in some patients with A-T may evidence an excessive activation of antitumour immunity, which needs to be studied.

Our study has shown that the main cause of mortality was infections (44.4\%), followed by cancer (25.9\%). Multivariate analyses of mortality factors in patients with A-T prove the associations between morbidity, mortality, and ATM genotype ${ }^{21}$. Biallelic mutations in ATM are associated with a high-risk of cancer (mainly hematologic malignancies) at young age, whereas hypo-morphic mutations in ATM have greater mortality from respiratory infections ${ }^{21}$. The high number of recurrent respiratory infections in A-T patients in this study was similar to others ${ }^{20}$, as well as the high mortality rate from infections also indicates the need to determine the genetic pattern of A-T in our population. The median survival in the Ukrainian population is low (16 years of age), and the twenty-year survival rate is $35 \%$, whereas in the French population the twenty-year old survival rate is higher (53.4\%), however it has not changed since $1954^{21}$. The early genetic diagnosis may impact treatment and preventive measures and help prolong the lives of patients and quality of their lives ${ }^{26-27}$.

\section{Conclusions}

Ataxia in combination with recurrent infections is the key to A-T diagnosis. In addition to syno-pulmonary infections, pyoderma and stomatitis are also frequent presentations. Infections and cancer are most often the causes of mortality in patients with A-T.

Children with ataxia should be referred to an immunologist, as well as genetic testing should be recommended for all patients with ataxia, for a timely diagnosis. Increasing knowledge about clinical and immunological presentation of A-T can also improve the early diagnosis, the management and prognosis of these patients.

\section{Authors' contributions}

The study conception and design by O.B., L.K., A.V., A.B. Material preparation, data collection and analysis were performed by O.B., L.K., A.B., A.H., Y.B., M.K., T.H., Y.S. The first draft of the manuscript was written by O.B. and all authors commented on previous versions of the manuscript. All authors have read and approved the final manuscript.

\section{Compliance with Ethics Requirements:}

„The authors declare no conflict of interest regarding this article"

"The authors declare that all the procedures and experiments of this study respect the ethical standards in the Helsinki Declaration of 1975, as revised in 2008(5), as well as the national law. Informed consent was obtained from the patients included in the study."

"No funding for this study"

\section{Acknowledgments}

The authors would like to thank the immunologists Oksana Malko, Iryna Hrabovska, Lyubov Dmytrash, Tetyana Grishyna for their collaboration; patients and their families for the participation in this study.

\section{References}

1. Rothblum-Oviatt C, Wright J, Lefton-Greif MA, McGrath-Morrow SA, Crawford TO, Lederman HM. Ataxia telangiectasia: a review. Orphanet J Rare Dis. 2016;11(1):159.

2. Schoenaker MHD, Blom M, de Vries MC, Weemaes CMR, van der Burg M, Willemsen MAAP. Early diagnosis of ataxia telangiectasia in the neonatal phase: a parents' perspective. Eur J Pediatr. 2020;179(2):251-256. 5

3. Nissenkorn A, Ben-Zeev B. Ataxia telangiectasia. Handb Clin Neurol. 2015;132:199-214.

4. Boder E. Ataxia-telangiectasia: an overview. Kroc Found Ser. 1985;19:1-63.

5. Tangye SG, Al-Herz W, Bousfiha A, et al. Human inborn errors of immunity: 2019 Update on the Classification from the International Union of Immunological Societies Expert Committee. J Clin Immunol. 2020;40(1):24-64.

6. Noordzij JG, Wulffraat NM, Haraldsson A, et al. Ataxia-telangiectasia patients presenting with hyper-IgM syndrome. Arch Dis Child. 2009;94(6):448-449. 
7. Van Os NJH, Haaxma CA, van der Flier M, et al. Ataxia-telangiectasia: recommendations for multidisciplinary treatment. Dev Med Child Neurol. 2017;59(7):680689.

8. Suarez F, Mahlaoui N, Canioni D, et al. Incidence, presentation, and prognosis of malignancies in ataxia-telangiectasia: a report from the French national registry of primary immune deficiencies. J Clin Oncol. 2015;33(2):202-208.

9. Jerzak KJ, Mancuso T, Eisen A. Ataxia-telangiectasia gene (ATM) mutation heterozygosity in breast cancer: a narrative review. Curr Oncol. 2018;25(2):e176-e180.

10. Nissenkorn A, Levy-Shraga Y, Banet-Levi Y, et al. Endocrine abnormalities in ataxia telangiectasia: findings from a national cohort. Pediatr Res. 2016;79(6):889-894.

11. Seidel MG, Kindle G, Gathmann B, et al. The European Society for Immunodeficiencies (ESID) Registry Working Definitions for the Clinical Diagnosis of Inborn Errors of Immunity. J Allergy Clin Immunol Pract. 2019;7(6):1763-1770.

12. Boyarchuk O, Balatska N, Chornomydz I. Evaluation of warning signs of primary immunodeficiencies. Pediatria Polska - Polish Journal of Pediatrics. 2019;94(6):337-341.

13. Hariyan $\mathrm{T}$, Kinash M, Kovalenko R, Boyarchuk O. Evaluation of awareness about primary immunodeficiencies among physicians before and after implementation of the educational program: A longitudinal study. PLoS ONE. 2020;15(5):e0233342.

14. Boyarchuk O, Dmytrash L. Clinical Manifestations in the Patients with Primary Immunodeficiencies: Data from One Regional Center. Turkish Journal of Immunology. 2019;7(3):113-119.

15. Hoche F, Seidel K, Theis M, et al. Neurodegeneration in ataxia telangiectasia: what is new? What is evident? Neuropediatrics. 2012;43(3):119-29.

16. Nowak-Wegrzyn A, Crawford TO, Winkelstein JA, Carson KA, Lederman HM. Immunodeficiency and infections in ataxia-telangiectasia. J Pediatr. 2004;144:505-511.

17. Boyarchuk O. Allergic manifestations of primary immunodeficiency diseases and its treatment approaches. Asian
Journal of Pharmaceutical and Clinical Research. 2018;11(11): 83-90.

18. Pasini AM, Gagro A, Roic G, Vrdoljak O, Luic L, Zutelij M. Ataxia-Telangiectasia and Juvenile Idiopathic Arthritis. Pediatrics. 2017;139(2):e20161279.

19. Kinash M, Boyarchuk O, Shulhai O, Boyko Y, Hariyan T. Primary immunodeficiencies associated with DNA damage response: complexities of the diagnosis. Arch Balk Med Union. 2020;55(3):11-18.

20. Thompson D, Duedal S, Kirner J, et al. Cancer risks and mortality in heterozygous ATM mutation carriers. J Natl Cancer Inst. 2005;97:813-22.

21. Micol R, Slama LB, Suarez F, et al. Morbidity and mortality from ataxia-telangiectasia are associated with ATM genotype. J Allergy Clin Immunol. 2011;128(2):382-389.

22. Voss S, Pietzner J, Hoche F, et al. Growth retardation and growth hormone deficiency in patients with Ataxia telangiectasia. Growth Factors. 2014;32(3-4):123-9.

23. Moin M, Aghamohammadi A, Kouhi A, et al. Ataxia-telangiectasia in Iran: clinical and laboratory features of 104 patients. Pediatr Neurol. 2007;37(1):21-28.

24. Stray-Pedersen A, Borresen-Dale AL, Paus E, Lindman CR, Burgers T, Abrahamsen TG. Alpha fetoprotein is increasing with age in ataxia-telangiectasia. Eur J Paediatr Neurol. 2007;11:375-380.

25. Driessen GJ, Ijspeert H, Weemaes CM, et al. Antibody deficiency in patients with ataxia telangiectasia is caused by disturbed B- and T-cell homeostasis and reduced immune repertoire diversity. J Allergy Clin Immunol. 2013;131:13671375.

26. Boyarchuk O, Volokha A, Hariyan T, et al. The impact of combining educational program with the improving of infrastructure to diagnose on early detection of primary immunodeficiencies in children. Immunologic Research. 2019;67(4-5):390-397.

27. Maródi L; J Project Study Group. The Konya Declaration for Patients with Primary Immunodeficiencies. J Clin Immunol. 2020;10.1007/s10875-020-00797-4. 